\title{
COMMENT
}

\section{ACCOUNTANTS' IIABILITY FOR NONDISCLOSURE OF POST-CERTIFICATION DISCOVERY OF ERROR}

The last thirty-five years have witnessed a steady and heated debate with respect to the proper limits of accountants' liabilities for damages which result from their certified audits. This controversy, which began in the wake of the landmark pronouncements in Ultramares Corp. $v$. Touche, ${ }^{1}$ took on a new importance with the extensive financial reporting requirements instituted a few years later by the Securities Acts. ${ }^{2}$ The role of accountants' services has grown with the development of an economic structure where, by means of the corporate device and credit transactions, industrial management is separated from the sources of funds.

Public accounting . . . bridges the gap between debtor and creditor and the purchaser and seller of securities. The principal function of the public accountant is to prepare statements diagnosing his clients' financial status, the client in turn using the statement as a passport for obtaining credit and selling securities. Because accounting requires specialized knowledge, millions of dollars are expended annually in reliance upon the accountants' diagnosis. ${ }^{3}$

The question of accountants' duties relative to certification has arisen in a new setting in the recent case of Fischer $v$. Kletz. ${ }^{4}$ In that case, Peat, Marwick, Mitchell \& Co. (PMM) had audited and certified the 1963 financial statements of Yale Express Systems, Inc., which were submitted to Yale stockholders and the SEC in April and June of 1964, respectively. ${ }^{5}$ After this certification was completed, PMM undertook "special studies" of Yale's income and expenses, which studies were to be used for internal purposes, rather than to serve as representations to the public. Figures uncovered in these studies clearly showed that the earlier certified statements had misstated Yale's financial position by a substantial, but indeterminate amount. Despite

1255 N.Y. 170, 174 N.E. 441 (1931).

2 Securities Act of 1933, 15 U.S.C. $\$ \$ 77 \mathrm{a}-\mathrm{bbbb}$ (1964); Securities Exchange Act of 1934, 15 U.S.C. $\$ \S 78 \mathrm{a}-\mathrm{jj}$ (1964); Investment Co. Act of 1940, 15 U.S.C. $\S \S 80 a-1-51$ (1964).

3 Meek, Liability of the Accountant to Parties Other Than His Employer for Negligent Misrepresentation, 1942 WIs. L. REv. 371.

4266 F. Supp. 180 (S.D.N.Y. 1967).

5 Certification of financial statements and submission to the SEC is required by Securities Exchange Act of 1934, § 13 (a) (2), 15 U.S.C. \& $78 \mathrm{~m}$ (a) (2) (1964). 
this discovery, made sometime in 1964, the errors were not disclosed by PMM either to management, the New York Stock Exchange (on which the securities were traded) or the public, until May, 1965. Plaintiffs, ${ }^{8}$ who had purchased Yale securities in reliance on the uncorrected 1963 statements after PMM's discovery of error, sought to recover resulting losses, claiming common law deceit and violation of section 10(b) of the Securities Exchange Act. ${ }^{7}$ Thus, the breach of duty alleged did not involve negligence or a plot to deceive in the original mistaken certification, but rather nondisclosure of an error discovered after the certification had become effective. The court's opinion, denying a motion to dismiss, reserved resolution of the issues raised for full development of the facts at trial.

The definition of accountants' duties upon discovery of error in certified statements should be made by considering the various interests involved. Those who have been damaged by reliance on false information which could have been corrected will seek compensation for their loss. The accountant who discovers the error has an interest in maintaining good relations with his client, and will be hesitant to make any disclosure which would jeopardize this relationship. The investing public's interest in the prompt restoration of accuracy in financial reports may be thought to conflict with the interests of stockholders in avoiding the loss of stock marketability that would result from speculative overreaction to news of the error.

It is likely that the dilemma of post-certification discovery of error will recur with greater frequency as dependence on accounting sources increases. This Comment therefore will deal with the broad problems inherent in this factual setting, by examining the two independently developed theories of liability suggested in Fischer: common law deceit and violation of section 10(b) of the Securities Exchange Act. This discussion will be followed by an exploration of the policy problems inherent in the imposition of such liability.

\section{Common Law Liability}

The accountant who undertakes to audit financial statements places upon himself distinct duties of care based independently on contract

6 The plaintiffs, who sued as a class, consisted of purchasers of Yale stock and debentures. The question of whether a class action was appropriate was decided in Fischer v. Kletz, 41 F.R.D. 377 (S.D.N.Y. 1966). Defendant's motion to dismiss or, in the alternative, to stay proceedings pending investigation by the ICC was denied in Fischer v. Kletz, 249 F. Supp. 539 (S.D.N.Y. 1966). See also Kaplan, Continuing Work of the Civil Committee: 1966 Amendments of the Federal Rules of Civil Procedure (I), 81 HARv. I. Rev. 356 (1967) ; Comment, Spurious Class Actionts Based Upon Securities Frands Under the Federal Rules of Civil Procedure, 35 Fordan L. REv. 295 (1966).

7 Plaintiffs also alleged violation of Securities Exchange Act of 1934, §18, 15 U.S.C. \&78r (1964). The questions presented by that allegation, which involve factual considerations not relevant here, are treated in $266 \mathrm{~F}$. Supp. at 189 . For a discussion of whether the existence of a remedy under $\$ 18$ for misleading certified statements precludes application of $\S 10(\mathrm{~b})$ to the present situation, see note 30 infra. 
and tort. ${ }^{8}$ The contractual duty extends only to the client who is party to the contract of employment and to third parties for whose benefit the contract was made. ${ }^{9}$ The tort duties extend to a potentially broader class of people and have been the subject of the controversy over accountants' liabilities to third parties for improper audit.

The principle that performance of a private contract can give rise to duties in tort ${ }^{10}$ was first tested with respect to auditing contracts in Ultramares Corp. $v$. Touche, ${ }^{11}$ where a corporation sued to recover the loss on a loan made in reliance on inaccurate financial statements certified by the defendant. After holding that the obligations of the auditing contract did not extend to the plaintiff corporation because it was not the intended beneficiary of the contract, ${ }^{12}$ Justice Cardozo ruled that tort recovery could be permitted only if defendant's misrepresentation amounted to fraud, rather than mere negligence. ${ }^{13}$ Noting the element of physical danger in previous cases which had recognized tort duties in the performance of contracts, the opinion suggests that such protection is less necessary where the duty involves words and thoughts rather than physical forces. ${ }^{14}$ A more basic concern was fear that expanded accountants' liabilities would spell financial ruin for the profession:

If liability for negligence exists, a thoughtless slip or blunder ... may expose accountants to a liability in an indeterminate amount for an indeterminate time to an indeterminate class. The hazards of a business conducted on these terms are so extreme as to enkindle doubt whether a flaw may not exist in the implication of a duty that exposes [sic] to these consequences. ${ }^{15}$

It may be questioned whether the Ultramares rule, denying rerecovery by third parties for negligence in financial reporting, is appli-

8 UItramares Corp. v. Touche, 255 N.Y. 170, 179, 174 N.E. 441, 444 (1931).

9 Id.

10 This principle was an innovation of the 19th century. See Thomas v. Winchester, 6 N.Y. 397 (1852). Prior to this development, recovery by third parties for injuries from negligent performance of contracts generally was rejected because of lack of contractual privity. See Winterbottom v. Wright, 10 M.\&W. 109, 152 Eng. Rep. 402 (1842). This restriction was first lifted in cases such as McPherson v. Buick Motor Co., 217 N.Y. 382, 111 N.E. 1050 (1916), permitting tort recovery by third parties where the defendant's breach created a danger of physical injury. See, e.g., Thomas v. Winchester, supra; Heaven v. Pender, 10 Q.B.D. 503 (1883).

11255 N.Y. 170,174 N.E. 441 (1931).

12 The court distinguished Glanzer v. Shepard, 233 N.Y. 236, 135 N.E. 275 (1922), which permitted a buyer of beans to recover against the weigher for negligently performing a weighing commissioned by the seller. Glanzer, in which reliance by the buyer was the "end and aim : : of the transaction," was an extension of the thirdparty beneficiary contract principles first set out in Lawrence v. Fox, 20 N.Y. 268 (1859), whereas in Ultramares, "No one would be likely to urge that there was a 255 N.Y. 170, 182-83, 174 N.E. 441 , $445-46$ (1931). . " Ultramares Corp. v. Touche,

13255 N.Y. at 189,174 N.E. at 448.

14 Id. at 181,174 N.E. at 445.

15 Id. at $179-80,174$ N.E. at 444. 
cable to the present problem. The reference in that decision to liability for a "thoughtless slip or blunder" seems to indicate a concern for the especially complex work of the auditor, in which the smallest mistake in calculation can lead to gross misrepresentations in certified statements. Appropriate as that concern may have been in Ultramares, it would have little relevance to the case of nondisclosure of discovered error, where the accountant's decision not to report his error in no way rested on "slips" in calculation.

There are, however, other elements in the Ultramares opinion which suggest that its intended scope does include this case. Despite the reference to the "thoughtless slip or blunder," Justice Cardozo makes no explicit suggestion that his rationale is in any way limited to cases of error in calculation. The factor which stands out as most essential to the decision is the threat of astronomical liabilities, ${ }^{16}$ which is equally present in improper certification cases regardless of the source of the error, and which may be as relevant to third party recoveries against negligent professionals in fields other than accounting. It is not surprising, therefore, that Judge Cardozo sees his fraudnegligence dichotomy as relevant far beyond the facts of Ultramares, and, indeed, to "many callings other than an auditor's." 17

Developments in professional liability insurance since the Ultramares decision throw the "financial ruin" rationale open to doubt. ${ }^{18}$ While the decision in Ultramares, on its facts, still may be justified in light of the extraordinary risk factor in the accounting function involved there, it is now questionable whether Justice Cardozo's broad conception of the rule should allow its extension to the ordinary-risk situation of an accountant's nondisclosure of discovered error. Thus, it is arguable that liability of the accountant in the present situation should be determined according to a simple negligence standard.

The imposition of liability, however, does not depend on rejection of the fraud-negligence dichotomy, since the accountant's nondisclosure of post-certification discovery of error contains the elements of common law fraud (deceit) as well as negligence. Although, generally nondisclosure is not actionable as deceit, ${ }^{19}$ there are exceptions to this rule. Where defendant reveals what to his knowledge is only a half truth, nondisclosure of the full information is actionable as deceit, ${ }^{20}$ and thus supports recovery by third parties. ${ }^{21}$ The discovery that a representa-

16 It has been so recognized by numerous commentators. See, e.g., Levitin, Accountants' Scope of Liability for Defective Financial Reports, 15 'HASTINGs L.J. 436, 446 (1964); Note, Potential Liability of Acconntants to Third Parties for Negligence, 41 St. JoHn's L. Rev. 588 (1967).

17255 N.Y. 170, 188, 174 N.E. 441, 448 (1931).

18 See text accompanying notes 54-61 infra.

19 W. Prosser, HandBook of the LaW of Torts, §101, at 701 (3d ed. 1964).

$20 \mathrm{Id}$. at 711.

21 State Street Trust Co. v. Ernst, 278 N.Y. 104, 15 N.E.2d 416 (1938) (accountant liable for failure to include material information pertaining to scope of audit). 
tion, which may have been true and complete when made, has proven false or incomplete at a later time, gives rise to a duty to reveal that discovery to anyone known to be relying on the original statement. ${ }^{22}$ Implicit in this principle is the assumption, basic to accountants' liability in the present situation, that a statement of fact made at a given point in time, which is intended to be relied on for some period in the future, is, in effect, a continuing representation for the entire period in which reliance is expected. Thus, when it is discovered during the period of continuing reliance that the original statement was incorrect, the representor commits a fraud by allowing the now conscious misrepresentation to continue in effect.

The fact that many of the cases allowing recovery for nondisclosure on the basis of deceit were cases in which the defendant stood to benefit financially from his deception raises the question of whether this factor is a prerequisite to liability. The presence of the element of personal enrichment in these cases should not be surprising, since the conception of fraud is generally associated with an intent to turn another's misinformation to one's own benefit. However, the suggestion that defendant's potential for gain is a necessary element of deceit liability in nondisclosure cases has been rejected when raised. In Goldsmith $v$. Koopman, ${ }^{23}$ where the deceit consisted of nondisclosure of information qualifying a representation made to plaintiffs, the court repudiated the gain prerequisite: "The complainants have been damaged to their hurt, and the defendant Koopman was a factor therein. That is the gravamen of the charge; not that defendant Koopman has gained, but that complainants have lost by his fault." 24 In a case much closer to the present problem, State Street Trust Co. v. Ernst, ${ }^{25}$ an accountant's nondisclosure was held to constitute fraud, despite the lack of any evidence of a motive to benefit. Where the accountant has no intention to defraud for his own gain, "heedlessness and reckless disregard of consequence may take the place of deliberate intention." ${ }^{26}$ Thus, while there has been no case dealing directly with

$22 \mathrm{~W}$. Prosser, supra note $19, \S 101$, at 711 . This principle has been applied where a buyer or seller of property failed to disclose to the other party changes in the value of the property, subsequent to negotiation, but prior to sale, Hush v. Reaugh, 23 F. Supp. 646 (E.D. Ill. 1938); Loewer v. Harris, 57 F. 368 (2d Cir. 1893); where a seller of equipment learned, subsequent to sale, but prior to full delivery, that the equipment was defective, Strand v. Librascope, $197 \mathrm{~F}$. Supp. 743 (E.D. Mich. 1961); where a representation of patentability by an inventor's agent proved incorrect while plaintiff was making payments to finance exploitation of the invention, Fitzgerald v. McFadden, 88 F.2d 639 (2d Cir. 1937) ; and in other analagous situations. See Schroeder v. Schroeder, 269 App. Div. 405, 56 N.Y.S.2d 36 (1945); cf. Piedmont \& Arlinton Life Ins. Co. v. Ewing, 92 U.S. 377 (1875); Stevens v. Marco, 147 Cal. App. 2d 357, 305 P.2d 669 (Dist. Ct. App. 1956).

23140 F. 616 (C.C.S.D.N.Y. 1905).

$24 I d$. at 621.

25278 N.Y. 104, 15 N.E.2d 416 (1938). See text accompanying notes $20-21$ supra.

26278 N.Y. at 112, 15 N.E.2d at $419 ; c f .$, James-Dickinson Farm Mortgage Co. v. Harry, 273 U.S. 119 (1927); Endsley v. Johns, 120 I11. 469, 12 N.E. 247 (1887); Sorenson v. Gardner, 215 Ore. 255, 334 P.2d 471 (1959); Boord v. Kaylor, 114 Ore. 62, 234 P. 263 (1925). 
the present situation of nondisclosure of subsequently discovered error by a person with nothing to gain financially from the nondisclosure, an accountant's failure to reveal such error falls within the scope of common law deceit as defined in Ultramares, and hence provides a basis for liability to third parties who rely to their detriment on the mistaken financial statements.

The foregoing analysis is a partial consideration of the merits of recognizing a common law duty of accountants to disclose postcertification discovery of error to third parties. It suggests merely that there is a foundation for such liability in the common law. Whether recognition of such a duty is wise as a matter of policy will be considered after discussion of the statutory basis for liability.

\section{LIABILITy UNDER RULE 10b-5}

A second basis for assessing liability may be contained in section 10 (b) of the Securities Exchange Act, ${ }^{27}$ and rule 10b-5 thereunder, ${ }^{2 s}$ which proscribe deception and fraud-by misrepresentation, omission or other act or scheme-in connection with securities transactions. Courts usually have implied a civil remedy for persons damaged by violation of these provisions. ${ }^{29}$ Thus, if nondisclosure of the discovery

27 Securities Exchange Act $\$ 10(\mathrm{~b}), 15$ U.S.C. $\$ 78 \mathrm{j}(\mathrm{b})$ (1964) :

It shall be unlawful for any person, directly or indirectly, by the use of any means or instrumentality of interstate commerce or of the mails, or, of any facility of any national securities exchange- $\therefore .$.

(b) To use or employ, in connection with the purchase or sale of any security registered on a national exchange or any security not so registered, any manipulative or deceptive device or contrivance in contravention of such rules and regulations as the Commission may prescribe as necessary or appropriate in the public interest or for the protection of investors.

2817 C.F.R. $\$ 240.10 \mathrm{~b}-5$ (1967) :

It shall be unlawful for any person, directly or indirectly, by the use of any means or instrumentality of interstate commerce, or of the mails or of any facility of any national securities exchange,

(a) To employ any device, scheme, or artifice to defraud,

(b) To make any untrue statement of a material fact or to omit to state a material fact necessary in order to make the statements made, in the light of the circumstances under which they were made, not misleading, or

(c) To engage in any act, practice, or course of business which operates or would operate as a fraud or deceit upon any person, in connection with the purchase or sale of any security.

${ }^{29}$ Kardon v. National Gypsum Co., 69 F. Supp. 512 (E.D. Pa. 1946) ; Hooper v. Mountain States Sec. Corp., 282 F.2d 195 (5th Cir. 1960); Errion v. Connell, 236 F.2d 447 (9th Cir. 1956); Speed v. Transamerica Corp., 235 F.2d 369 (3rd Cir. 1956) ; Fischman v. Raytheon Mfg. Corp., 188 F.2d 783 (2d Cir. 1951) ; cf. J. I. Case Co. v. Borak, 377 U.S. 426 (1964) ; Boone v. Baugh, 308 F.2d 711 (8th Cir. 1962); Texas Continental Life Ins. Co. v. Dunne, 307 F.2d 242 (6th Cir. 1962); Estate Counselling Serv., Inc. v. Merrill Lynch, Pierce, Fenner \& Smith, Inc., 303 F.2d 527 (10th Cir. 1962). Contra, Jordan Bldg. Corp. v. Doyle, O'Connor \& Co., [1966-7 Transfer Binder] CCH FED. SEC. L." Rep. T 91,996 (D. Iil. 1967). The appropriateness of any retrospective federal remedy for the victim of a violation of rule $10 \mathrm{~b}-5$ has been subject to considerable controversy. For discussion of this broader problem; see Fleischer, "Federal Corporation Law": An Assessment, 78 HARV. L. REv. 1146; 
of error is held to be deception within the scope of the rule, recovery in the present situation could be awarded to those injured by the uncorrected financial statements "in connection with the purchase or sale of any security." 30 The limitation of rule $10 \mathrm{~b}-5$ to deception in connection with securities transactions makes a remedy under it unavailable to those injured by lending money to the corporation, or by entering into a transaction involving no purchase or sale of securities. ${ }^{31}$

Historically, courts have construed rule $10 \mathrm{~b}-5$ to cover a wide range of situations. The concept of fraud which has emerged from this liberality is at least as broad as the common law doctrine which

1170 (1965) ; Ruder, Civil Liability Under Rule 10b-5: Judicial Review of Legislative Intent?, 57 Nw. U.L. REv. 627 (1963); Joseph, Civil Liability under Rule 10b-5A Reply, 59 Nw. U.L. Rev. 171 (1964); Ruder, Pitfalls in the Development of a Federal Law of Corporations by Implication through Rule 10b-5, 59 Nw. U.L. REv. 185 (1964).

30 It should be noted that the existence of $\$ 18$ of the Exchange Act, 15 U.S.C. \$78r (1964), dealing specifically with misleading statements in documents filed with the SEC, does not preclude recovery under rule $10 \mathrm{~b}-5$. Section 18 itself is inapplicable to nondisclosure of after-acquired information. Included in the provision are requisites that the original document be a willful misstatement when filed, and that it be shown that plaintiff bought or sold "at a price which was affected by such statement"-an impossible burden. Further, the scope of $\S 18$ 's effectiveness is substantially curtailed by the short, one year statute of limitations. 15 U.S.C. $\$ 78 \mathrm{r}$ (c) (1964). The narrowness of these provisions raises doubts as to whether the section could have been intended as the sole restriction in the Exchange Act on misstatements in documents filed with the Commission. The Exchange Act is not a coordinated, section by section approach to the separate problems which plagued the securities markets. Rather, it "contains a miscellaneous collection of provisions involving securities regulation . . R. BAKER \& W. CARY, CASES AND Materials on CoRPorations 564 (3d ed. 1958). Although various sections of the Act may have differences in coverage or phraseology, they obviously can overlap. 3 L. LOSS, SECURITIES REgulation 1428-29 (2d ed. 1961) [hereinafter cited as Loss]. And $\$ 10(\mathrm{~b})$ is one of those sections which most clearly extends to problems partially dealt with elsewhere. Indeed, the section has been held to support a fraud action based on misstatements in documents filed with the SEC. Miller v. Bargain City, U.S.A., Inc., 229 F. Supp. 33 (E.D. Pa. 1964). The question of liability under $\$ 10(\mathrm{~b})$ therefore can be dealt with solely in terms of interpretation of that section, with no concern for preemption of liability by $\S 18$.

31 Birnbaum v. Newport Steel Corp., 193 F.2d 461 (2d Cir. 1952), cert. denied 343 U.S. 956 (1952), held that only purchasers or sellers of securities could recover under rule 10b-5. The declaration has had considerable impact: ". . . in order to limit recoverable damages to losses closely connected with securities trading, courts have universally required that the plaintiff's injury result from his purchase or sale of securities." Note, Civil Liability Under Section 10(b) and Rule 10b-5: A Suggestion for Replacing the Doctrine of Privity, 74 Y YLE L.J. 658, 661 (1965).

Some courts have gone beyond this strict limitation. E.g., Vine v. Beneficial Finance Co., 374 F.2d 627 (2d Cir. 1967) and Voege v. American Sumatra Tobacco Corp., 241 F. Supp. 369 (D. Del. 1965) (both holding stockholder, who will be forced to sell his stock because of a short-form merger, is allowed to sue for damages under rule 10b-5) ; Moore v. Greatamerica Corp., CCH FED. SEc. L. REP. II 91,953 (N.D. Ohio May 18, 1967) (corporation, neither purchaser nor seller, is allowed to bring an action to enjoin consummation of fraudulent tender offer under rule $10 \mathrm{~b}-5$ ) ; Stockwell v. Reynolds, 252 F. Supp. 215 (S.D.N.Y. 1965) (finding liability where the only securities transaction was a sale made at a loss after the damage from restraint from selling because of misstatement was already done); M. L. Lee \& Co. v. American Cardboard \& Packaging Corp., 36 F.R.D. 27 (E.D. Pa. 1964) (finding liability where there was no actual purchase or sale).

The conflict over the Birnbaum limitation of liability to suits only by buyers or sellers is discussed in Comment, Private Enforcement Under Rule 10b-5: An Injunction for a Corporate Issuer?, 115 U. PA. L. REv. 618, 620-25 (1967). 
it complements. ${ }^{32}$ The language of the rule indicates that a broad definition of fraud was contemplated. For example, 10b-5 explicitly includes omissions as well as active representations, ${ }^{33}$ and extends to acts that would "operate as a fraud," 34 rather than merely to acts which are technically within the common law definition. Nonetheless, the remedy has not yet been applied against a disinterested accountant who fails to disclose his post-certification discovery of error. Imposition of liability in the above situation must be considered in light of the legitimate concerns that the rule may impose astronomical liabilities on an indeterminate class of defendants, ${ }^{35}$ and become the basis for a new, all encompassing "federal corporation law." 38

The fear that the risk of unlimited liability will discourage performance of vital economic functions has led to a search for means of restricting application of rule $10 \mathrm{~b}-5 .^{37}$ One limiting principle, conceivably implicit in the development of the remedy thus far, is that an action will lie only against those defendants who stood to benefit from their deception. Such a rule would allow the anti-fraud provisions to ensnare only those offenders whose position in the transaction suggests improper motives, while leaving the disinterested reporter free from fear that his "thoughtless slip," with no intention to benefit himself,

32 See SEC v. Capital Gains Research Bureau, Inc., 375 U.S. 180 (1963) ; List v. Fashion Park, Inc., 340 F.2d 457 (2d Cir.), cert. denied, 382 U.S. 811 (1965); Ellis v. Carter, 291 F.2d 270 (9th Cir. 1961) ; Weber v. C.M.P. Corp., 242 F. Supp. 321 (S.D.N.Y. 1965); Cochran v. Channing Corp., 211 F. Supp. 239 (S.D.N.Y. 1962) ; 3 Loss $1430-44$.

3317 C.F.R. $\$ 240.10 \mathrm{~b}-5$ (b) (1967).

3417 C.F.R. $\$ 240.10 \mathrm{~b}-5$ (c) (1967) (emphasis added).

35 Painter, Inside Information: Growing Pains for the Development of Federal Corporation Law Under Rule 10b-5, 65 Colum. L. Rev. 1361 (1965); Ruder, Civil Liability Under Rule 10b-5: Judicial Revision of Legislative Intent, $57 \mathrm{Nw}$. U.L. REv. 627 (1963) ; Note, Civil Liability, supra note 31, at 658.

36 See Birnbaum v. Newport Steel Corp., 193 F.2d 461 (2d Cir.), cert. denied, 343 U.S. 956 (1952); Ruder, supra note 35.

37 The search for a way to limit the extent of potential liability without curtailing the effectiveness of the rule in controlling deception and manipulation in securities transactions has produced a wide range of possible solutions. The early attempt to limit recovery to those in privity, Joseph v. Farnsworth Radio \& Television Corp., 99 F. Supp. 701,706 (S.D.N.Y. 1951), proved unsatisfactory. See Freed v. Szabo Food Serv., Inc., [1961-4 Transfer Binder] CCH FED. SEC. L. REP. II 91,317 (N.D. Ill. 1964); Cochran v. Channing Corp., 211 F. Supp. 239 (S.D.N.Y. 1962) ; Brown v. Bullock, 194 F. Supp. 207 (S.D.N.Y. 1961); Texas Continental Life Ins. Co. v. Banker's Bond Co., 187 F. Supp. 14 (W.D. Ky. 1960), rev'd on other grounds, 307 F.2d 242 (6th Cir. 1962); Note, Civil Liability, supra note 31 , at $658,663-65$, and authorities cited therein. For an earlier discussion of the prospects for the privity doctrine, see 3 Loss 1767. Although reliance by the plaintiff has been held necessary to recovery, it has been liberally construed, e.g., List v. Fashion Park, Inc., 340 F.2d 457, $463-64$ (2d Cir.), cert. denied, 382 U.S. 811 (1965), and has been subject to vigorous criticism as a means of limiting liability. Painter, supra note 35 , at $1366-71$. In addition, some narrowing of duties has been achieved by applying a conservative definition to "materiality." See SEC v. Texas Gulf Sulphur Co., 258 F. Supp. 262, 280 (S.D.N.Y. 1966). Finally, it has been suggested that civil liability for some cases that fall within the rule's scope give way to other disciplinary action by the SEC. Painter, silpra note 35 , at 1361. To the extent that compensation of those damaged is deemed central to the Exchange Act's scheme of regulation, however, imposition of liability cannot be replaced by SEC disciplinary action. Thus the legitimate question of how to limit liability without thwarting the purpose of the Exchange Act remains, 
will ruin him financially. The attractiveness of this limitation has been recognized in several recent cases.

In Cochran v. Channing Corp., the court suggested that "it is the use of the inside information that gives rise to a violation of rule 10b-5." 38 Further, in SEC v. Texas Gulf Sulphur Co., Judge Bonsal declared:

In the absence of a showing that the purpose of the . . . press release was to affect the market price of TGS stock to the advantage of TGS or its insiders, the issuance of the press release did not constitute a violation of Section $10(\mathrm{~b})$ or Rule $10 \mathrm{~b}-5 . . .^{39}$

Although these statements indicate that courts have been reluctant to impose liability on defendants whose actions were not prompted by selfish motives, recovery has not yet turned on the issue of defendant's standing to benefit. The statement in Cochran was made in an opinion which found liability, and hence was extraneous to the decision. ${ }^{40}$ In Texas Gulf Sulphur, the absence of gain was only one reason why the court refused to find liability for a press release issued to combat rumors of a valuable mineral discovery by defendant corporation. The court also found that the release was not intended to, and did not in fact, produce unusual market action, ${ }^{41}$ and that no demonstration had been made that the release was false or deceptive. ${ }^{42}$ Thus, the court's suggestion that an intention to benefit either defendant or an insider is necessary to establish liability under rule $10 \mathrm{~b}-5$ was made in a setting where the defendant was not only devoid of selfish motives, but did not make any misrepresentation at all. As such, its force is open to doubt.

Indeed, there have been cases where recovery has been permitted in the absence of personal gain by the defendant. As the court noted in Fischer $v$. Kletz, defendants who have been held liable under the rule have included not only insiders, broker-dealers and corporations whose stock is purchased or sold, but also those who aid and abet or conspire with such parties. ${ }^{43}$ These cases indicate that the concern has been not so much with penalizing only those who stood to gain by misleading the public, as with punishing those whose misrepresentation or failure to disclose was conscious, rather than accidental..$^{44}$

38211 F. Supp. 239, 243 (S.D.N.Y. 1962) (emphasis added).

39258 F. Supp. 262, 294 (S.D.N.Y. 1966) (emphasis added).

40 See Fleischer, supra note 29, at 1157 n.51.

41258 F. Supp. at 294.

$42 I d$. at 294-96.

43266 F. Supp. at 190.

44 See Pettit v. American Stock Exchange, 217 F. Supp. 21 (S.D.N.Y. 1963); H. L. Green Co. v. Childree, 185 F. Supp. 95 (S.D.N.Y. 1960) ; SEC v. Timetrust, Inc., 28 F. Supp. 34 (N.D. Cal. 1939); Burley \& Co., 23 S.E.C. 461 (1946); 3 Loss 1476. 
Where there is a conspiracy or where defendant acts to aid and abet another, such consciousness is evident. When defendant misleads in such a way that he stands to gain from his victim's ignorance, consciousness and intent are presumed.

A rule limiting liability to conscious misrepresentations seems ideal in its application to the present problem. An accountant who certifies incorrect financial statements would be free, under this standard, from fear of 10b-5 liability so long as his only contribution to the mistake was an unintentional error or miscalculation in the preparation of statements. However, if and when he becomes aware of his mistake and consciously fails to make a disclosure of the error, damages should be assessed. Since the defendant whose breach comes within such limits would be fully aware of the deception involved, he hardly could protest his innocence. ${ }^{45}$

This reading of the statute is consistent with the legislative history of the Exchange Act. Application of the anti-fraud provisions to those who stand to benefit from their deception serves a major purpose of the Act by curtailing self-serving schemes to milk investors. ${ }^{46}$ However, Congress' concern in 1934 was not limited to deterring such selfish exploitation. The Act also was designed to accomplish the more encompassing function of insuring market stability by restoring investor confidence. ${ }^{47}$ Effectuation of this goal only can be achieved by safeguarding investment information against conscious deception, as well as intentional fraud.

A second concern which has been voiced in considering extensions of rule $10 \mathrm{~b}-5$ is that liberal construction will transform the rule from a securities market regulation into a basis for a new "federal corporation law." 48 This fear received its first, and most well known

45 The accountant who fails to disclose his post-certification discovery of error might well come within the rule even if the "standing to benefit" limitation were to prevail. The nondisclosure will often be caused by a combination of desire to avoid the adverse publicity which might be stimulated by reports of error, and an intention to please his client in order to assure continuance of the account. While such motives are slightly different than an intent to enrich oneself directly by buying or selling stock at an unfair advantage, they nonetheless provide a factor of gain and it is difficult to see a real basis for distinguishing them from other selfish intentions. It also should be noted that, while standing to benefit is not an across the board prerequisite to 10b-5 liability, it may be quite relevant in certain circumstances. Thus, where the alleged deception involved mere nondisclosure and no actual misstatement, the failure to report news may be attributed to concern for the effects disclosure would have on the corporation. The weight given to such a motive in determining liability under rule $10 \mathrm{~b}-5$ rightly should depend upon the defendant's standing to benefit from his silence.

46 This concern is amply reflected in the report of the Committee on Interstate and Foreign Commerce, where there is a full review of methods by which channels of information and the pricing mechanisms of the securities markets could be made to serve illegitimate personal interests. 78 CoNG. REc. 7704 (April 30, 1934).

47 Id. at 7702-03.

48 This concern is based on the numerous applications of rule $10 \mathrm{~b}-5$ in areas unaffected by the federal interest in national securities markets. Allowing recovery where the transaction in question was between two stockholders in a close-corporation, as in Kardon v. National Gypsum Co., 73 F. Supp. 798 (E.D. Pa. 1947), extends 
expression in Birnbaum v. Newport Steel Corp., where Judge Augustus Hand declared that "Section 10(b) . . . was directed solely at the type of misrepresentation or fraudulent practice usually associated with the sale or purchase of securities rather than fraudulent mismanagement of corporate affairs . . ." 49 The attempt in Birnbaum to remove corporate management problems from the reach of $10 \mathrm{~b}-5$ reflects "a reluctance of federal courts to preempt areas of traditional state law concern." 50 While this general principle has had wide judicial acceptance, ${ }^{51}$ it has undergone some modification. Thus, in Pettit $v$. American Stock Exchange, the court recognized that prevention of deception in national securities markets and the adjudication of internal mismanagement decisions necessarily overlap, and therefore redefined federal jurisdiction to exclude only cases where the purchase or sale of securities is merely "incidental to a major mismanagement issue." 52 The present case of failure to disclose post-certification discovery of error is certainly not excluded by this standard. Courts have suggested that, in order for a deception to be "in connection with the purchase or sale of any security," it must have been intended to affect such purchase or sale. ${ }^{53}$ Clearly, this connection with securities transactions is present in the case of financial statements compiled and audited for submission to the SEC. The purpose of filing such statements is to provide information upon which rational investment decisions can be made. Thus, while manipulation of the market may not be intended, market reliance certainly is. The importance of accuracy in certified financial statements to the information flow in national

the rule to private frauds. Allowing recovery where the fraud relates to the value of consideration for securities, rather than the value of the securities themselves, Errion v. Connell, 236 F.2d 447 (9th Cir. 1956), goes beyond the solution of securities market fraud problems: "The [Exchange Act] is aimed at frauds growing out of the very complexity of securities transactions, and the fact that the casual investor is in a poor position to ascertain the truth of representations made concerning securities. Such disabilities do not exist in the case of most forms of consideration given for securities." Comment, Rule X-10b-5: An Unlikely Basis for Expanding Jurisdiction, 9 STAN. L. REv. 589, 596 (1957). This same complaint applies where recovery is based on fraudulent nonpayment of the agreed price of securities. A. T. Brod \& Co. v. Perlow, 375 F.2d 393 (2d Cir. 1967). It can be further argued that allowing recovery by a corporation which has been defrauded in the issuance of its own stock, Hooper v. Mountain States Sec. Corp., 282 F.2d 195 (5th Cir. 1960), cert. denied, 365 U.S. 814 (1961), also reaches beyond the securities markets. See Comment, Rule X-10b-5 Protection Extended to Issuing Corporation, 13 Stan. L. Rev. 378 (1961).

49193 F.2d 461, 464 (2d Cir.), cert. denied, 343 U.S. 956 (1952).

50 See Comment, Private Enforcement Under Rule 10b-5: An Injunction for a Corporate Issuer?, 115 U. PA. L. REV. 618, 621 (1967).

51 See, e.g., O'Neill v. Maytag, 339 F.2d 764 (2d Cir. 1964) ; Comment, supra note 50 , at 621 and sources cited therein.

62217 F. Supp. 21, 25 (S.D.N.Y. 1963).

53 SEC v. Texas Gulf Sulphur Co., 258 F. Supp. 262, 294 (S.D.N.Y. 1966); Heit v. Weitzen, [1964-6 Transfer Binder] CCH FED. SEC. L. REP. IT 91,701 (S.D.N.Y. 1966) ; Freed v. Szabo Food Serv., Inc., [1961-4 Transfer Binder] CCH FED. SEC. L. REP. $\pi 91,317$ (N.D. III. 1964). 
securities markets provides the federal interest necessary for application of rule $10 \mathrm{~b}-5$ to accountants' nondisclosure of post-certification discovery of error.

\section{Policy Implications of Liability}

The fact that there exists a basis for imposing liability does not speak to the question of how well such a solution will resolve the problems created by an accountant's post-certification discovery of error. The most apparent benefits of a damage remedy for nondisclosure include compensation to those injured in reliance on the uncorrected statements, and an incentive toward prompt disclosure of the error. In addition to these more obvious features, however, there are some important problems inherent in the imposition of liability for nondisclosure. This section will consider whether these dangers outweigh the significant advantages gained by permitting recovery.

\section{Fears of Ruinous Liability}

The most widely voiced criticism of an expansion of accountants' liability is that the added financial burden would be ruinous to the profession. In a recent article, a senior partner in Peat, Marwick, Mitchell \& Co. asserted that: "If the independent accountant's responsibility for financial statements extended as far as some plaintiffs in current litigation claim it does, independent public accountants could no longer afford to practice their profession." 54 Justice Cardozo's expression of concern for limitless liabilities in Ultramares ${ }^{55}$ has become a rallying cry for those who argue for narrow interpretation of the accountant's legal duties.

The legitimate fear of unlimited liability has little application to situations where, as here, liability is confined to instances involving conscious breach of a duty. Because the obligation turns on the accountant's awareness of his error, the power to limit liability is in his hands and, hence, the financial burden cast upon the accounting profession is likely to be quite limited. ${ }^{56}$

The possibility that this added burden will lead to financial ruin is especially remote in light of the extensive development of professional liability insurance in recent years. ${ }^{57}$ The American Institute of Certi-

54 Hanson, Responsibilities of Independent Public Accountants, 22 Bus. LAwYER 975 (1967).

55 See text accompanying notes 11-15 supra.

56 Although the growth of the large accounting firms has resulted in some loss of control by the firm organizations over partner accountants, the firm nonetheless still retains as much control over the work of individual partners as is present in the normal corporate situation; this should be sufficient protection against excessive liability. It is only proper that the firm should suffer for the lapses of its partners, in much the same way any principal may suffer liability for the breaches of its agents.

57 See American Instrtute of Certified Public Accountants, Insurance for Accounting Firms and Practimioners (Economics of Accounting Practice, Bull. 10, 1959). 
fied Public Accountants reports that sizeable policies are carried by the vast majority of accounting firms. ${ }^{58}$ It has been argued that an expansion of liability will result in driving the cost of professional insurance to the point where either the insurance will have to be dropped or the auditors' fees greatly swollen by the costs of protection. $^{59}$ The limited incidence of liability that can be expected to result from recognition of accountants' duties to disclose discovery of error likely would not lead to any substantial effects on the price of either insurance or accounting services. However, to the extent that any increase in auditing costs results, the enormous burden of damages caused by the failure to correct the original statements will be spread over the economy, and thus be more easily borne. ${ }^{60}$ One writer, in considering the consequences of broadening accountants' liabilities, reached the following conclusion:

The courts have been markedly solicitous for the accountant's economic circumstances . . . [I]n light of the economic maturity of the independent accounting profession, further dependence on judicial tenderness seems ill founded. . . . [I]n 1960, Fortune IMagazine estimated that the top eight public accounting firms employed about 15 per cent. of the nation's approximately 77,000 Chartered Public Accountants. Together, it was estimated, these accounting houses annually grossed over $\$ 200,000,000$. Furthermore, a typical firm was thought to carry about $\$ 15,000,000$ in insurance.

Maintenance of a sound economy through the building and preservation of investor confidence in the securities markets and corporate management is far more important than the private need of the accounting profession to be free of a threatened liability for fraud against which ample protection can be taken.

The legal duties of the auditor ought to be co-extensive with his professional pretensions. ${ }^{\text {II }}$

\section{Protection of the Accountant-Client Relationship}

Because of the likely possibility that, as in Fischer, an accountant's post-certification discovery of error will be made while the accountant

58 Id. at 5.

69 It is likely that higher premiums would have the most devastating effect on the small individual accountant who operates on a relatively small margin. This pressure, in turn, may necessitate the amalgamation of these units into entities which can more easily absorb this large added expense. See Editorial, The Specter of Auditor's Liability, J. Accountancy, Sept. 1965, at 34.

60 Cf. C. Morris, Torts 16-17, 246-55 (1953).

61 Bradley, Liability to Third Persons for Negligent" Audit, 1966 J. Bus. LAw $190,195-96$. 
is doing internal work for the corporation (which, in itself, entails none of the public responsibility involved in certification), the recognition of a duty to disclose may be attacked as a violation of the confidential relationship between accountant and client. Concern within the profession for the protection of this relationship has grown as reliance on accountants' services has increased. As a result, there has been agitation in recent years for the recognition of an accountantclient evidentiary privilege. ${ }^{62}$

The policy of protecting confidential communications between accountant and client, which is embodied in the growing list of statutes recognizing the evidentiary privilege, will not be at all compromised by liability for nondisclosure of post-certification discovery of error. It is essential to remember that the purpose of a privilege for confidential communications is to encourage the free exchange of information necessary to a relationship which is deemed to have a great social value. The scope of such a privilege is accordingly limited to serve this function:

(1) The communications must originate in a confidence that they will not be disclosed.

(2) This element of confidentiality must be essential to the full and satisfactory maintenance of the relation between the parties.

(3) The relation must be one which in the opinion of the community ought to be sedulously fostered.

(4) The injury that would inure to the relation by the disclosure of the communications must be greater than the benefit thereby gained for the correct disposal of litigation. ${ }^{63}$

These limitations provide the basis for the widely recognized privilege for communications made in the course of seeking or receiving legal advice from a lawyer. ${ }^{64}$ The attorney-client privilege, on which the call for an accountant-client privilege is largely based, ${ }^{65}$ reflects a judgment that an attorney's complete awareness of his client's position is essential in performing his role of obtaining justice for that client. The social value of such awareness is thought sufficient to justify recognition of a communications privilege. ${ }^{66}$ In the accountant-client relationship, it is difficult to perceive a similar value sufficient to justify protecting the client's admission (or the accountant's discovery) of financial ir-

62 Fourteen states have enacted legislation extending some degree of protection to the accountant-client relationship. See Katsoris, Confidential Communications-The Accountants' Dilemma, 35 FoRDHAM L. Rev. 51, 55-64 (1966).

63 8 J. WIGMORE, EvIDENCE \$2285, at 527 (McNaughton rev. ed. 1961).

$64 \mathrm{Id}$. $\$ 2292$, at 554 .

65 See Katsoris, supra note 62 , at 53-55.

66 C. MCCorMICK, Evidence $\$ 91$, at 181 (1954). 
regularity. Since the accountant, unlike the attorney, serves the public primarily as a reporter, rather than as an advocate, communications which do not somehow enhance his ability to report accurately are of questionable social value. To protect discovery of financial irregularities from public disclosure would be to void the primary benefit which can be served by such a discovery.

While the protective policy of a communications privilege is inapplicable to the present problem, it might be argued that the accountant's fear of ill-will from his client, resulting from the accountant's disclosure of irregularities or errors to the proper authorities, would serve to deter him from making such disclosures. In order to ease this awkward situation, the accountant should be permitted to make the initial disclosure of error directly to his client. If after being informed of the discovery of mistakes, the client fails to disclose the information promptly to the appropriate authorities, the accountant would be obligated to do so himself, in order to avoid possible liability. ${ }^{67}$

\section{Prevention of Overreaction by the Securities Markets}

The discovery of error in already-released financial statements raises the difficult question of how to correct the error quickly, without inducing speculative overreaction in the market for the corporation's securities. The danger is that disclosure of bad news about the corporation will cause investors to panic, driving the price of the stock down further than news of the error warrants. When the price of the securities is far below their proper value, the effect is to deny a market for their stock to those who already hold shares. The threat of overreaction is especially severe in situations like that in Fischer, where, although a mistake is recognized, the correct figures are not yet known. Yet, the effect of withholding the news in order to avoid market overreaction would be to invite further commitments of money to the corporation based on faulty information. Although, in transactions involving the transfer of securities before disclosure of the error, there might be instances where the effect of the sale would be to relieve the seller of overvalued stock bought and held on the basis of the misinformation, securities sales by sellers who have not relied on the misinformation would involve no such redeeming feature. Moreover, failure to correct the statements may have effects beyond the securities markets, allowing extensions of additional credit to the corporation at a time when repayment is unlikely.

67 A rule limiting the accountant's duty to disclosure to his client, and shifting all responsibility for further disclosure to the informed client, might endanger the important purposes behind the imposition of liability. It is quite possible that the client will have no incentive for disclosure, either because the mistake was part of an intentional scheme to defraud, in which case a new basis for liability would have little deterrent effect, or because damages for nondisclosure will be uncollectible because of the client's financial condition. In the latter situation, which is certainly possible in cases of erroneous financial statements, there would be no source of compensation for those injured by the client's nondisclosure. 
The destablizing effects of news of the discovered errors may well be minimized by resort to suspension of trading in the corporation's securities. Such a step, which can be taken by either the stock exchange on which the securities are traded ${ }^{68}$ or the SEC, ${ }^{69}$ has been utilized with increasing frequency in recent years. ${ }^{70}$ Trading has been suspended most often in situations like that discussed here, where information about the corporation was either unreliable or unavailable, and the suspensions generally have extended until such time as an accurate picture of the corporation's position could be presented. ${ }^{\mathbf{7 1}}$ It should be noted that, despite increasing use of the suspension power, the tendency has been away from suspension in cases where, even with complete reporting of the company's condition, there is uncertainty over its future prospects. ${ }^{72}$ Thus, a decision to suspend trading will not involve a denial of an opportunity for stockholders to unload their stock quickly at relatively high prices based on legitimate hopes for the company's health, but rather will be confined to situations where no such intelligent judgment to buy could be made. Further, it can hardly be claimed that stock prices will always be lower after suspension of trading than they would be immediately after disclosure of the error, since the investigation of the corporation's finances pending resumption of trading may well reveal smaller losses than those

68 E.g., New York Stock Exchange Rule 499, CCH NYSE Guide \2499 (1967).

69 Securities Exchange Act of 1934, \$19(a) (4), 15 U.S.C. \$ 78s(a) (4) (1964).

70 No suspensions of trading were ordered in the years 1934-1943. The following table, compiled after independent examination of the public releases, provides a breakdown of SEC suspensions by year:

$\begin{array}{llrr}1944 & 1 & 1956 & 2 \\ 1945 & 1 & 1957 & 2 \\ 1946 & 2 & 1958 & 2 \\ 1947 & 0 & 1959 & 3 \\ 1948 & 1 & 1960 & 1 \\ 1949 & 0 & 1961 & 4 \\ 1950 & 0 & 1962 & 6 \\ 1951 & 0 & 1963 & 2 \\ 1952 & 0 & 1964 & 1 \\ 1953 & 2 & 1965 & 11 \\ 1954 & 0 & 1966 & 14 \\ 1955 & 0 & \text { Sept. } 1967 & 24\end{array}$

71 E.g., Northern Instrument Corp., SEC Securities Exchange Act Release Nos. 8061 (April 21, 1967) and 8142 (August 11, 1967) (SEC suspends over-the-counter trading in corporation's securities after receiving letter from corporation stating that former president of corporation caused the books to overstate assets); American Plan Corp., SEC Securities Exchange Act Release Nos. 8091 (May 29, 1967) and 8097 (June 5, 1967) (SEC suspends over-the-counter trading after learning that company's figures, based on contractual commitments held at time statements were filed, had become incorrect in light of failure of the other contracting party); Sports Arenas, Inc., SEC Securities Exchange Act Release Nos. 8005 (December 7, 1966) and 8102 (June 13, 1967) (SEC suspends over-the-counter trading because of lack of reliable information concerning the company's financial condition; annual financial reports were submitted more than 6 months late, and were sufficiently confused as to lead the auditors to refuse certification); Wall Street Journal, June 19, 1967, at 8, col. 3 (American Stock Exchange orders trading halt in shares of Scurry-Rainbow Oil Ltd. at the request of company, pending an important announcement concerning discovery of Canadian oil reserves).

72 Compare cases cited in note 71 supra with those collected in 2 Loss 852-53. 
anticipated by the market. Although freezing holdings of the corporation's stock by the suspension of trading would involve the serious consequence of tying up the funds of stockholders, the avoidance of the tremendous dangers of nondisclosure or destablizing speculation that such action would achieve seems well worth this cost. In order to allow for such suspension when appropriate, disclosure of error should be made to the exchange on which the corporation's securities are traded, or, in the case of over-the-counter issues, to the SEC. ${ }^{73}$

\section{ConcLusion}

As the above discussion indicates, the decision to interpret the common law of deceit or section 10(b) of the Securities Exchange Act as providing liability for an accountant's nondisclosure of his postcertification discovery of error would entail certain costs to the accounting profession, and to the investing public as a whole. The liability would inevitably create some financial burden. Disclosure of error in accordance with the duty suggested will have some disruptive effects on securities markets. Some friction between the accountant and his client will likely be created. But these costs are clearly outweighed by the financial burdens and disruptions of securities markets that would result from the failure of the accountant to publicize his findings of error in certified financial statements. These dangers to the financial community are so great as to call for the recognition of the suggested duty of disclosure.

73 The considerations involved in deciding whether to suspend trading are different if the discovery of error is accompanied by discovery of the correct figures. In such a case, immediate release of the corrected statements would not create the void of uncertainty suggested above. However, significant problems-prejudice to investors with unequal access to the notice and overreaction in the form of panic selling $\longrightarrow$ would still remain. See generally S. RobBIns, The Securities Market (1966). The decision of whether these factors are sufficient to require suspension of trading, despite the burdens that such action places on the securities markets as well as the suspending agency, is one which should be made by the agency itself. Therefore, even when the accountant is able to provide figures to replace the previously certified misstatement, disclosure should be made to the exchange or the SEC before further publication. 